Egyptian J. Anim. Prod.,Vol. 31,Supplement Issue, Nov.(1994):601-611.

\title{
EFFECT OF FEEDING AND HOUSING SYSTEMS ON THE PERFORMANCE OF BUFFALO CALVES RAISED DURING SUMMER SEASON
}

\author{
T.M. El-Bedawy', M.A.M. Salama², Sabbah M. Allam' and \\ S.S. $\operatorname{Kha} 1 i 1^{2}$ \\ 1- Department of Animal production, Faculty of \\ Agriculture, University of Cairo, Giza, Egypt, 2- Animal \\ production Research Institute, Ministry of Agriculture, \\ Cairo, Egypt
}

\section{SUMARARY}

A number of 24 one week-old buffalo calves born during April through June were used in $2 \times 2$ factor factorial design to study the effect of milk feeding level on feed intake, weight gain, rumen fermentation and phyalological response of calves housed either indoor or outdoor in wooden hutches during summer season. Milk was fed at levels of 8 or 10 of birth weight in constant amount from one week old up to weaning. Calf starter and berseem hay were fed ad. 1ib. starting on first day of the experiment. Calves were weaned whenever they achieved ary matter intake from the plant feed of about $600 \mathrm{~g} /$ head/day. After weaning, calves were moved in one group. Feed and water intakes, ruminal and physiological parameters were biweekly measured before weaning. Body weight was recorded before weaning and up to 26 weeks of age.

Pre-weaning body weight and average daily gain (ADG) were greater $(\mathrm{P}<0.05)$ for calves fed $10 \% \mathrm{milk}$ level than those fed $8 \% \mathrm{milk}$ level. Calves housed outdoor showed insignificant higher $A D G$ than those housed indoor. The pre-weaning average daily gain in weight (g/day) was $468,522,578$ and 598 for groups 88 -housed indoor, $8 \%-$ housed outdoor, 10\%-housed indoor and 10\%-housed outdoor, respectively. The corresponding weaning ages were $66,56,61$ and 55 days. Outdoor housing system

Issued by Egyprian Sociery of Animal Production. 
saved 9 days of milk feeding for calves fed $8 \%$ milk level and 6 days for those fed $10 \% \mathrm{milk}$ level. Calves fed $10 \%$ milk levels consumed more TDN and CP than those fed $8 \%$ milk level.

pre-weaning dry feed intake, body weight and feed conversion were not significantly affected by milk intake level, housing system and their interaction.

Neither milk intake level nor housing system significantly influenced ruminal pH, total VFA's concentrations, molar proportions of acetate, propionate or butyrate. Respiration rate was higher in calves housed in the outdoor hutches. However, rectal temperature and pulse rate were not significantly affected by the treatments.

post-weaning body weight and $A D G$ up to six months of age were not significantly influenced by either pre-weaning milk feeding level or housing system. However, calves fed $10 \%-\mathrm{milk}$ level and housed indoors. tended to have', slightly heavier body weight and greater average daily weight gain.

Keywords: Buffalo calves, milk intake, housing system, growth performance, rumen fermentation

\section{INTRODUCTION}

The expensive traditional systems tó raise buffalo calves in Egypt respecting the great amount of consumed milk and the relative long milk feeding period have gtimulated many attempts to apply different systems of early weaning using whole buffalo milk (Borhami et al.., 1967; Khoury et al., 1967; Salama et $\underline{\text { al., }} 1989$ and El-Bedawy et al., 1989).

The facilities of conventional housing system for pre-weaned calves are not available for many of dairy producers especially the small holders. still a moderate healthy housing system is required since calves have been successfully raised in calf hutches without respiratory diseases or other problems of humidity and spread of pathogenic organisms (Jaster et al., 1990).

The objective of the present study was to evaluate the pre-weaning performance of buffalo calves raised on low milk intake, housed in outdoor hutches and weaned at a certain dry feed intake. 
MATERIALS AND METHODS

Twenty four one week old buffalo calves were randomly distributed into four groups each of six calves in $2 \times 2$ factor factorial arrangement to study the effect of milk intake level and housing system on the pre-weaning calf performance. The experiment was carried out at Mehallet-Mousa Research Station during the early summer season (from April to July) with average environmental temperature of $29^{\circ} \mathrm{C}$ and relative humidity of $90 \%$ throughout the experimental period.

Milk was bucket fed at level of $8 \%$ or $10 \%$ of birth weight as a constant amount up to weaning. The daily milk allowance was fed in two equal portions twice daily at $8: 30$ and 15:30. Calf starter (408 cottonseed and linseed meals, 208 yellow corn, 268 wheat bran, 48 rice bran, 78 sugarcane molasses, $2 \% 1$ imestone and $1 \%$ common salt) and berseem hay were offered ad libitum from the seventh day of age to the end of the trial. Water and mineral blocks were available. Calves were weaned whenever their dry matter intake from both hay and starter was about $600 \mathrm{~g} /$ day. Chemical composition of feeds was determined according to A.O.A.C. (1980). Chemical composition and nutritive value of whole buffalo milk, berseem hay and calf starter are shown in Table 1 .

Table 1. Chemical composition and nutritive value of the experimental feeds

\begin{tabular}{lccr}
\hline Composition, 8 & $\begin{array}{c}\text { Buffalo } \\
\text { milk }\end{array}$ & $\begin{array}{l}\text { Calf } \\
\text { starter }\end{array}$ & $\begin{array}{c}\text { Berseem } \\
\text { hay }\end{array}$ \\
\hline Dry matter & 15.05 & 90.66 & 88.94 \\
Organic matter & 14.27 & 82.97 & 78.37 \\
Crude protein & 3.08 & 17.33 & 15.05 \\
Ether extract & 6.20 & 4.45 & 2.75 \\
Crude fiber & 0.00 & 6.03 & 26.83 \\
N-free extract & 4.99 & 55.16 & 33.74 \\
Ash & 0.78 & 7.16 & 10.57 \\
TDN & 17.78 & 63.68 & 46.40 \\
\end{tabular}

Daily feed and water intakes were individually measured for all calves twice weekly. Birth weight was 
recorded not later than 24 hr after birth. Calves were weekly weighed to the nearest kilogram throughout the period from birth to weaning. After weaning calves were moved to one group and weighed once a week up to 26 weeks of age.

During milk feeding period, rumen fluid samples were biweekly collected from all calves before and $4 \mathrm{hr}$ after milk feeding. Ruminal pH was immediately measured using pH-meter, total VFA's concentrations (Kromann et al., 1967) and molar proportions of VFA's (Erwin et al., 1961) were determined. Rectal temperature, respiration rate and pulse rate were biweekly measured for all calves at $2.00 \mathrm{pm}$ prior the second milk feeding.

Data collected were statistically analyzed using the General Linear Model (GLM) of SAS (1982). Duncan's multiple range test was applied when the main effect of the treatments; was significant. The used model was as follows:

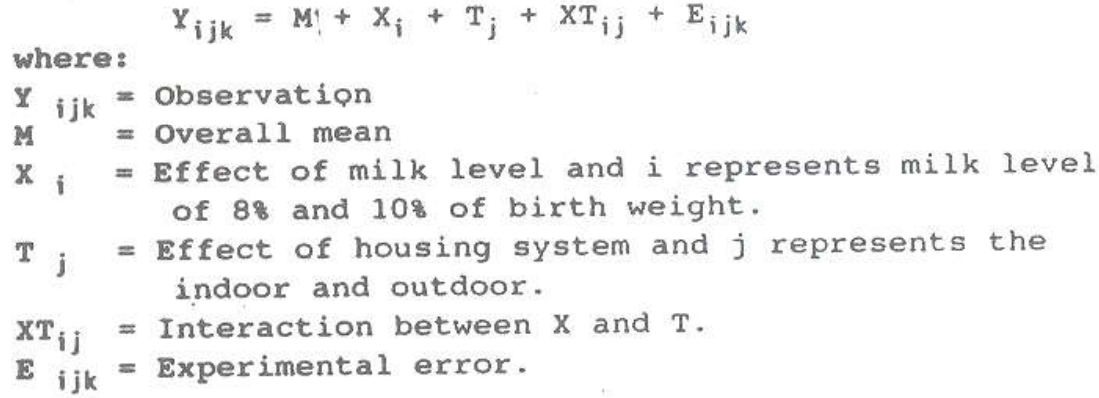

RESULTS AND DISCUSSION

Data of feed, water and nutrient intakes are presented in Table 2. Milk intake level or housing system had no significant effect on average weaning age, feed and water intakes. However, calves fed high milk level tended to consume less hay and water specially those kept indoor. The highest starter intake (164 g/day) and the lowest hay intake (92 g/day) was observed for the 108 milk-indoor group (group 3). Roy (1980) reported that the quantity of hay consumed by a calf is largely dependent on the amount of concentrate offered. The intake from TDN and $C P$ was found to be parallel to DM intake.

Outdoor housing system was associated with lower starter intake, higher hay intake and shorter weaning 
age of calves by 10 days for low milk level group and 6 days for the high milk level group since calves were weaned whenever their voluntary daily DM intake from hay and starter was as much as $600 \mathrm{~g} / \mathrm{head} / \mathrm{day}$.

Table 2. Effect of milk intake level and housing system on average daily feed and water intake by preweaned buffalo calves

\begin{tabular}{|c|c|c|c|c|c|}
\hline \multirow[b]{2}{*}{ Items } & \multicolumn{2}{|r|}{$8 \%$} & \multicolumn{2}{|r|}{$10 \%$} & \multirow[b]{2}{*}{ SE } \\
\hline & $\ln$ & Out & In & Out & \\
\hline Milk consumption, $\mathrm{Kg}$ & $2.88 b$ & $2.94 \mathrm{~b}$ & $3.51 \mathrm{a}$ & $3.31 \mathrm{a}$ & 0.16 \\
\hline Weaning age, day & 66 & 56 & 61 & 55 & 6 \\
\hline $\begin{array}{l}\text { Average dry matter intake, } \mathrm{Xg} \\
\text { Milk }\end{array}$ & $0.433 b$ & $0.443 \mathrm{~b}$ & $0.528 a$ & $0.498 \mathrm{a}$ & 0.024 \\
\hline Starter & 0.145 & 0.140 & 0.164 & 0.140 & .0 .029 \\
\hline Hay & 0.127 & 0.151 & 0.092 & 0.136 & 0.030 \\
\hline Total & 0.705 & 0.734 & 0.784 & 0.774 & 0.044 \\
\hline Average drinking water intake & & & & & \\
\hline L/h/day & 1.95 & 2.04 & 1.34 & 2.03 & 0.25 \\
\hline Average TON intake, $\mathrm{Kg} / \mathrm{h} /$ day & & & & & \\
\hline Milk & 0.511 & 0.523 & 0.624 & 0.588 & 0.029 \\
\hline Starter & 0.093 & 0.089 & 0.104 & 0.089 & 0.018 \\
\hline Hay & 0.059 & 0.070 & 0.043 & 0.043 & 0.063 \\
\hline Total & $0.663 \mathrm{~b}$ & $0.682 \mathrm{~b}$ & $0.771 \mathrm{a}$ & $0.740 \mathrm{a}$ & 0.034 \\
\hline Average $\mathrm{CP}$ intake, $\mathrm{Kg} / \mathrm{h} / \mathrm{day}$ & & & & & \\
\hline Milk & $0.089 \mathrm{~b}$ & $0.091 \mathrm{~b}$ & $0.108 a$ & $0.102 a$ & 0.005 \\
\hline Starter & 0.026 & 0.025 & 0.029 & 0.025 & 0.005 \\
\hline Hay & 0.019 & 0.023 & 0.014 & 0.021 & 0.005 \\
\hline Total & 0.134 & 0.139 & 0.151 & 0.148 & 0.008 \\
\hline
\end{tabular}

$\bar{a}, \bar{b}$ Means within rows with unlike superscripts differ $(\mathrm{P}<0.05)$.

Water intake was the most affected parameter by housing system. Calves raised outdoor consumed more water than those kept indoors. It might be due to the direct exposure to the high environmental temperature $\left(29^{\circ} \mathrm{C}\right)$. The negative relationship between water intake and milk intake (Salama et al.,1989) was confirmed only for the groups housed indoor since decreasing milk intake level from $10 \%$ to $8 \%$ of birth weight increased water intake from 1.34 to 1.95 liter h/day. This relationship was not proven in calves housed outdoors. However, comparable high water intake was observed in calves housed outdoors either fed high or low milk level. Body weight, gain and feed conversion are shown in Table 3. Calves fed the higher milk level and housed in door were slightly heavier at weaning $(72.3 \mathrm{Kg})$ than those fed the low milk level either kept indoor 167.7 
$\mathrm{Kg})$ or outdoor $(68.3 \mathrm{Kg})$. However, these differences were not significant. At weaning, calves fed $10 \%$ milk level and housed in door was slightly heavier than those kept outdoors. Such trend was not proven for calves fed $8 \%$ milk. This result might due to the shorter weaning age of outdoor groups. Borhami et al. (1967), Khoury et al. (1967 and Salama et al. (1989) found that the early calves fed low milk and early weaned were slightly lighter than late weaned ones and maintained these differences up to $\mathrm{six}$ month of age.

Table 3. Effect of milk intake level and housing system on body weight, average daily gain (ADG) and feed conversion by pre-weaned buffalo calves

\begin{tabular}{|c|c|c|c|c|c|}
\hline \multirow[b]{2}{*}{ I tems } & \multicolumn{2}{|c|}{$8 \%$} & \multicolumn{2}{|c|}{$10 \%$} & \multirow[b]{2}{*}{ SE } \\
\hline & In & Out & In & Out & \\
\hline \multicolumn{6}{|l|}{ Body weight, $\mathrm{Kg}$} \\
\hline $\begin{array}{l}\text { Birth } \\
\text { Weaning }\end{array}$ & $\begin{array}{l}37.8 \\
67.7\end{array}$ & $\begin{array}{l}39.8 \\
68.3\end{array}$ & $\begin{array}{l}31.2 \\
72.3\end{array}$ & 68.2 & $\begin{array}{l}2.2 \\
2.6\end{array}$ \\
\hline 26 weeks & 125.9 & 121.7 & 133.0 & 127.0 & $\begin{array}{l}2.0 \\
8.5\end{array}$ \\
\hline \multicolumn{6}{|l|}{$\begin{array}{l}26 \text { weeks } \\
\text { Gain, } \mathrm{Kg}\end{array}$} \\
\hline Birth to weaning & 29.8 & 28.5 & 35.2 & 32.2 & 2.9 \\
\hline Weaning to 26 weeks & 58.2 & 48.4 & 60.7 & 58.8 & 7.2 \\
\hline Birth to 26 weeks & 88.0 & 81.9 & 95.9 & 91.0 & 8.8 \\
\hline \multicolumn{6}{|l|}{$\begin{array}{l}\text { Birth to } 26 \text { weeks } \\
\text { ADG, g/day }\end{array}$} \\
\hline $\begin{array}{l}\text { Birth-weaning } \\
\text { Weaning- } 26 \text { weeks }\end{array}$ & $\begin{array}{l}468 b \\
498\end{array}$ & $\begin{array}{l}522 b \\
433\end{array}$ & $\begin{array}{l}578 a \\
508\end{array}$ & $\begin{array}{l}598 a \\
459\end{array}$ & $\begin{array}{l}42 \\
49\end{array}$ \\
\hline $\begin{array}{l}\text { Weaning- } 26 \text { weeks } \\
\text { Birth to } 26 \text { weeks }\end{array}$ & $\begin{array}{l}498 \\
484\end{array}$ & $\begin{array}{l}433 \\
450\end{array}$ & 527 & 500 & 49 \\
\hline \multicolumn{6}{|l|}{$\begin{array}{l}\text { Birth to } 26 \text { weeks } \\
\text { Pre-weaning feed conversion }\end{array}$} \\
\hline DM & 1.55 & 1.43 & 1.38 & 1.32 & 0.09 \\
\hline TDN & 1.47 & .1 .34 & 1.35 & 1.26 & 0.10 \\
\hline $\mathrm{CP}$ & 0.29 & 0.27 & 0.27 & 0.25 & 0.02 \\
\hline
\end{tabular}

a, b Means within rows with unlike superscripts differ $(P<0.05)$.

Neither milk intake level nor housing system had significant effect on the total gain before and after weaning up to six months of age. However, calves fed milk at level of 108 of their birth weight gained more weight than those fed 88 milk of birth weight. The effect of housing system on the total gain of calves was dependent on their age and milk intake level. Calves housed indoors tended to gain more weight than those kept outdoors both before and after weaning particularly those fed the low milk level. This could be attributed to the longer time required for weaning.

Average daily weight gain (ADG) was calculated to avoid the differences in weaning age among the four 
groups. The average weaning age was $66,56,61$. and 55 days for group $1,2,3$ and 4 , respectively. Pre-weaning ADG of 108-groups was higher $(P<0.05)$ than that of 88-groups because of the higher milk TDN intake of 108 -group by 228 for those kept indoor and by 128 for those kept outdoor.

Economides and Georghiades (1984) reported that the pre-weaning daily gain of Friesian calves decreased with decreasing milk intake. Housing system had no significant effect on ADG either pre- or post-weaning. However, slightly higher ADG was observed in calves housed outdoor before weaning because of theix shorter weaning age. Jorgenson et al. (1970) found that pre-weaned calves housed indoor had slightly higher daily weight gain than calves housed in hutches. The opposite trend was observed after weaning or during the entire period of six months. Economides and Georghiades (1984) found that the post weaning growth between 8 and 12 weeks of age was inversely related to the pre-weaning weight gain.

The feed conversion was calculated as $\mathrm{Kg}$ dry matter, TDN and DCP required for $1 \mathrm{Kg}$ gain. The best relative feed conversion was recorded for the group fed $10 \% \mathrm{milk}$ level and housed outdoors. The outdoor housing system improved the feed conversion by calves fed either $8 \%$ or $108 \mathrm{milk}$ level. The $8 \% \mathrm{milk}$ level-outdoor group (group 2) showed almost similar feed conversion as the $108-\mathrm{milk}$ level-indoor group (group 3).

The effect of milk intake level and housing system on rumen fermentation is shown in Table 4. Neither milk intake level nor housing system had significant effect on ruminal $\mathrm{pH}$ and total VFA's concentrations. Ruminal $\mathrm{pH}$ slightly decreased and total VFA's concentrations increased at $4 \mathrm{hr}$ post-feeding compared with their values before feeding. The lower ruminal pH after milk feeding might be due to the high level of lactic acid probably accumulated (Roy 1980). The molar proportions of ruminal volatile fatty acids were not affected by milk intake level except the before feeding isovalerate which increased by increasing milk intake. El-Bedawy et al. (1989) found no effect of reducing milk intake by $50 \%$ on molar proportion of ruminal volatile fatty acids during the first 15 week of age. Housing system did not significantly affect the molar proportion of ruminal volatile fatty acids except for butyrate, iso-butyrate 
and iso-valerate before feeding. Molar proportions of butyrate increased $(P<0.05)$ while iso-butyrate and iso-valerate decreased $(\mathrm{P}<0.05)$ in calves kept indoor.

Table 4. Effect of milk intake level and housing system on rumen fluid pH, volatile fatty acid's concentration by pre-weaned buffalo calves

\begin{tabular}{|c|c|c|c|c|c|}
\hline \multirow{2}{*}{ I trems } & \multicolumn{2}{|c|}{$8 \%$} & \multicolumn{2}{|c|}{$10 \%$} & \multirow[b]{2}{*}{$\mathrm{SE}$} \\
\hline & In & Out & In & Out & \\
\hline \multicolumn{6}{|l|}{ pH } \\
\hline Before feeding, & 6.60 & 7.00 & 6.73 & 6.90 & 0.14 \\
\hline $4 \mathrm{hr}$ post-feeding & 5.43 & 6.68 & 6.73 & 6.75 & 0.16 \\
\hline \multicolumn{6}{|l|}{ VFA's concentrations } \\
\hline Before feeding, & 3.43 & 2.45 & 3.02 & 2.82 & 0.39 \\
\hline 4. hr post-feeding & 3.44 & 2.96 & 3.38 & 3.52 & 0.30 \\
\hline \multicolumn{6}{|c|}{ Acetate molar proportion } \\
\hline Before feeding, & 54.42 & 58.77 & 55.39 & 46.13 & 3.13 \\
\hline $4 \mathrm{hr}$ post-feeding; & 51.72 & 57.83 & 54.64 & 43.37 & 3.34 \\
\hline \multicolumn{6}{|c|}{ Propionate } \\
\hline Before feeding, & 22.27 & 19.98 & 20.13 & 28.28 & 2.76 \\
\hline $4 \mathrm{hr}$ post-feeding & 22.36 & 20.99 & 19.61 & 25.49 & 2.73 \\
\hline \multicolumn{6}{|c|}{ Butyrate } \\
\hline Before feeding, & 15.46 & 11.30 & 15.85 & 11.71 & 2. 18 \\
\hline $4 \mathrm{hr}$ post-feeding & 15.92 & 13.04 & 16.98 & 17.58 & 2. 18 \\
\hline \multicolumn{6}{|l|}{ Iso-butyrate } \\
\hline Before feeding, & 2.21 & 2.83 & 2.40 & 3.82 & 0.35 \\
\hline $4 \mathrm{hr}$ post-feeding & 2.55 & 2.64 & 2.55 & 3.39 & 0.42 \\
\hline \multicolumn{6}{|l|}{ Iso-valerate } \\
\hline Before feeding, & $2.65 c$ & $4.05 b$ & $3.84 b$ & $5.74 a$ & 0.58 \\
\hline $4 \mathrm{hr}$ post-feeding & 3.49 & 3.37 & 3.95 & 4.74 & 0.65 \\
\hline Valerate & & & & & - \\
\hline Before feeding, & 3.01 & 2.99 & 2.41 & 4.30 & 0.68 \\
\hline $4 \mathrm{hr}$ post-feeding & 3.89 & 2.14 & 3.31 & 5.45 & 0.82 \\
\hline \multicolumn{6}{|c|}{ Acerate: propionate ratio } \\
\hline Before feeding, & 2.54 & 3.05 & 2.87 & 1.87 & 0.37 \\
\hline $4 \mathrm{hr}$ post-feeding & 2.55 & 2.64 & 2.55 & 3.39 & 0.42 \\
\hline
\end{tabular}

$a, b, c$ Means within rows with unlike superscripts differ $(P<0.05)$.

No significant differences were detected in body temperature and pulse rate among the experimental groups (Table 5). However, respiration rate was higher $(P<0.05$ ) for groups housed outdoor. This might be related to the direct exposure of calves kept outdoors to the stress which resulted from the high average ambient temperature $\left(29^{\circ} \mathrm{C}\right)$ and relative humidity (90\%) outside the pens during the experimental period. Pulse rate was slightly higher in calves housed outdoors. Milk intake had no significantly effect on body temperature, respiration and pulse rate. However, Huber et al. (1984) found that 
increasing milk intake increased the rectal temperature (Table 5).

Table 5. Effect of milk intake level and housing system on body temperature ${ }^{\circ} \mathrm{C}$, respiration rate and pulse rate by pre-weaned buffalo calves

\begin{tabular}{|c|c|c|c|c|c|}
\hline \multirow[b]{2}{*}{ I tems } & $8 \%$ & \multicolumn{2}{|c|}{$10 \%$} & \multirow[b]{2}{*}{ Out } & \multirow[b]{2}{*}{ SE } \\
\hline & In & Out & In & & \\
\hline Body temperature & 39.0 & 39.0 & 39.9 & 39.0 & 0.1 \\
\hline Respiration rate & $33 a$ & $61 \mathrm{~b}$ & $40 \mathrm{a}$ & $57 b$ & 4 \\
\hline Pulse rate & 50 & 63 & 52 & 54 & 4 \\
\hline
\end{tabular}

a Means within rows with unlike superscripts differ $(P<0.05)$

From technical viewpoint, It could be concluded that buffalo calves could be raised successfully by feeding milk at rate of $8 \%$ of the birth weight fed in constant amount from birth to weaning and weaned whenever they could achieve $600 \mathrm{~g} / \mathrm{h} / \mathrm{day}$ plant feed intake. The outdoor hutches could be used for housing during summer season since outdoor housing system resulted in shorter weaning age and improved the feed efficiency in comparison with the conventional type of calf houses. Yet, the economic comparison should be considered.

\section{REFERENCES}

A.O.A.C., 1980. Official Methods of Analysis (13th Ed.). Association of official Analytical Chemists. Washington, DC.

Borhami, B.E.A., K. El-Shazly, A.R. Abou Akkada and I.A. Ahmed, 1967. Effect of early establishment of ciliate protozoa in the rumen on microbial activity and growth of early weaned buffalo calves. J. Dairy Sci., 50:1654.

Economides, S. and E. Georghiades, 1984. The effects of weaning age, quantity of milk, once daily feeding and form of concentrates on the performance of Friesian calves. Nutr. Abst. \& Rev.,53:1472.

El-Bedawy, T.M., M.A.M. Salama and L.H. Bedier, 1989. Effect of restricted milk intake on productive performance of buffalo calves up to six months of age. Proc. of The 3rd Egyptian-British Conference on Animal, fish and Poultry production. 
Alexandria-Egypt, 7-10 October.

Erwin, E.S., G. J. Marco and E.M. Emery, 1961. Volatile fatty acid analysis of blood and rumen fluid by gas chromatography. J. Dairy Sci., 44:1768.

Hubber, J.T., A.G. Silva, O.F. Comos and C.M. Mathieu, 1984. Influence of feeding different amounts of milk on performance, health and absorption capability of body calves. J. Dairy Sci., 67:2957.

Jaster, E.H., G.C. McCoy and R.L. Fernado, 1990. Dietary fat in milk or milk replacers for dairy calves raised in hutches during the winter. J. Dairy Sci., $73: 1843$.

Jorgenson, L.J., N.A. Jorgensen, D.J.M. Schingoethe, and M.J. Owens, 1970. Indoor versus outdoor calf rearing at three weaning age. J. dairy Sci., $53: 813$."

Khoury, F.K., IiA. Ahmed and K. El-Shazly, 1967. Early weaning in cow and water buffalo calves (Bos Bubalus L.). 1. Growth rates, efficiency of feed utilization and cost of unit gain. J. dairy Sci., $50: 1661$.

Kromann, R.P., H.J. Meyer and W.J. Stielau, 1967. Steam distillation of volatile fatty acids in rumen digesta. J. Dairy Sci., 50:73.

Roy, J. H. B. 1980. The Calf. 4th Ed. Butterworths, London-Boston.

Salama, M.A.M., T.M. El-Bedawy, L.H. Bedier, 1989. Effect of early weaning on productive performance of buffalo calves up to six months of age. Proc. of The 3rd Egyptian-British Conference on Animal, fish and Poultry Production. Alexandria-Egypt, 7-10 october.

SAS User's guide: Statistics. 1982. SAS Inst. Cary, NC. 
تأثيز نظاهى التنفية و المسكن على أداء العجول الجاهوسىى فـلال فصل

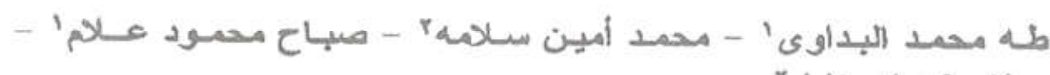
صفاء شعبان خليل مديل

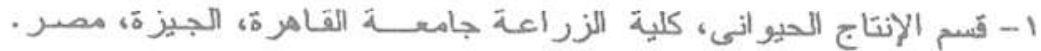

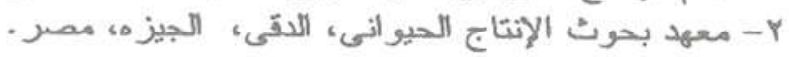

فى تجربة مصدمه بنظام 2 factorial أستخدم فيها الربعة وعشرون

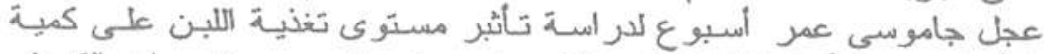

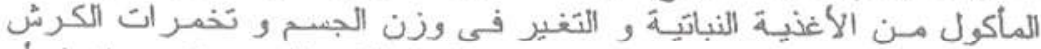

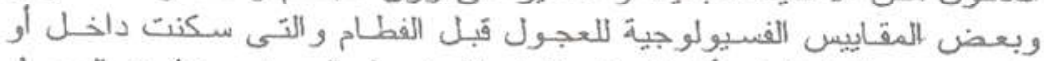

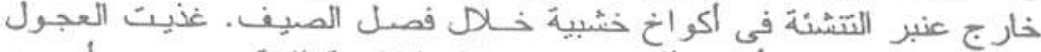

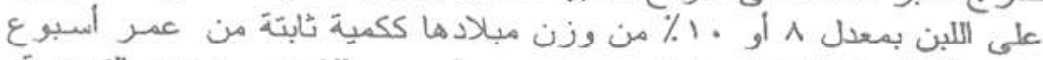

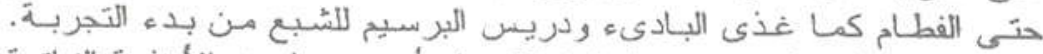

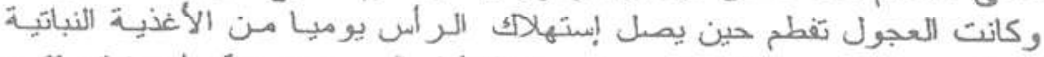

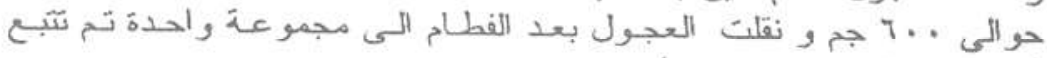

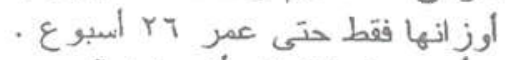

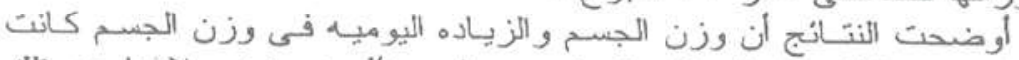

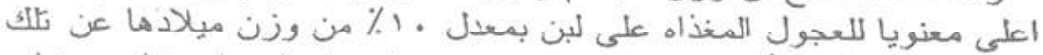

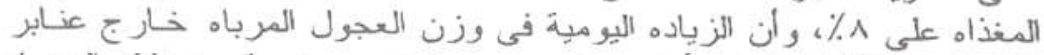

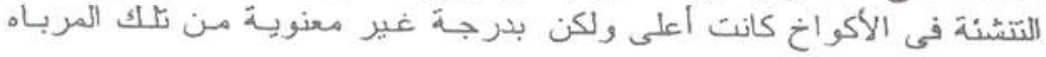

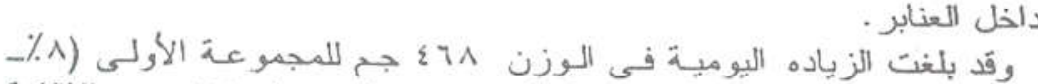

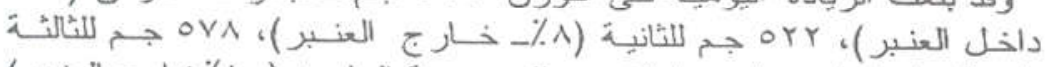

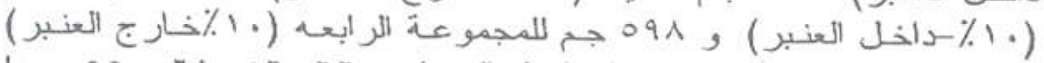

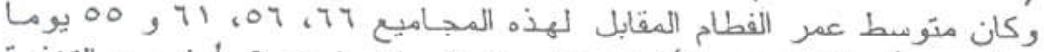

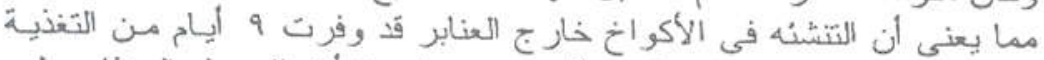

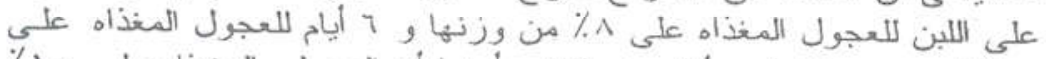

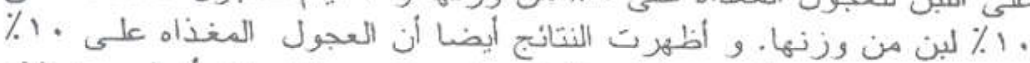

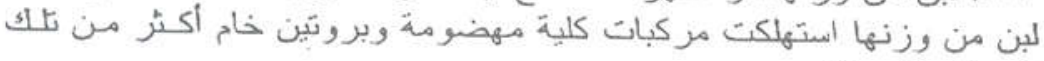

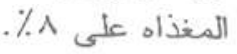

